\title{
Histopathological pattern of testicular lesion
}

\author{
Baidya $\mathrm{R}^{1}$, Sigdel B ${ }^{1}$, Baidya $\mathrm{NL}^{2}$ \\ ${ }^{\prime}$ Department of Pathology, B\&B Hospital, Lalitpur, Gwarko, Nepal \\ ${ }^{2}$ Department of General Surgery, B\&B Hospital, Lalitpur, Gwarko, Nepal
}

\section{Keywords:}

Mixed germ cell tumor; Non-Hodgkin lymphoma; Seminoma; Testicular tumors

\begin{abstract}
Background: Testicular tumors are rare type of tumors affecting adolescents and young adults. The testicular tumors constitute 4th most common cause of death from neoplasm in a younger male.The present study is undertaken to analyze the pattern and age wise distribution of testicular lesions in our hospital.
\end{abstract}

Materials and Methods: This was a prospective study done over a period of 4 years from November 2012 to October 2016, after taking approval of the ethics committee and informed consent from the patients. Histopathological slides were retrieved and reviewed for tumor and its subtype.

Results: A total of 60 cases of testicular lesions were encountered in our study. Out of the total 60 cases, $15 \%$ (9/60) were diagnosed as malignant testicular tumor. Most of these tumors were seen between $3 \mathrm{rd}$ and 4 th decades. Germ cell tumor was the most common type $(77.7 \%)$ among which seminomas $(44.44 \%)$ and mixed germ cell tumors $(28.57 \%)$ were most frequently encountered. Other tumor diagnosed was Non-Hodgkin lymphoma. Non-neoplastic lesions of the testis are most common in the second decade of life. The youngest patient was at birth and oldest was 71 years of age. Out of all nonneoplastic lesions, vascular lesions like torsion and infarction are the most common findings (54.90\%) followed by tuberculous abscess $(15.68 \%)$.

Conclusion: Testicular tumors are uncommon in our population. Histopathological spectrum of our study was comparable with other parts of the world,germ cell tumor accounted for highest percentage of cases in neoplastic lesions and torsion and infarction are the common findings in non-neoplastiic lesions of testis.

\section{INTRODUCTION}

Testicular cancers comprise $1 \%$ of all the male cancers worldwide. ${ }^{1}$ In developed countries, testicular neoplasm

\section{Correspondence:}

Dr. Reena Baidya, $M D$

Assistant Professor,Department of Pathology,

$B \&$ B Hospital, Kantipur Dental College \& Research Center, Nepal

E-mail: reenashrest@hotmail.com have been noted as most common solid tumor between the $2^{\text {nd }}$ and $4^{\text {th }}$ decade of life. ${ }^{2,3}$ Though the etiology of testicular cancer is not well understood, various factors like cryptoorchidism, trauma, infections, genetic and endocrine factors appear to play a role in their development. ${ }^{4}$ A definite geographic and racial distribution is seen in testicular tumors. The age distribution of testicular cancer is also distinct from other cancers. ${ }^{5}$ 
Table 1: Histological diagnosis of testicular tumor along with age distribution.

\begin{tabular}{cccccc}
\hline Age group & Seminoma & MGCT & NHL & Immature Teratoma & Total \\
\hline $31-40$ & 2 & 2 & 1 & - & 1 \\
$41-50$ & 1 & - & - & - & $2(55.55 \%)$ \\
$51-60$ & - & - & - & - & 0 \\
$61-70$ & - & - & - & - & $1(11.11 \%)$ \\
$71-80$ & - & - & - & - & $1(11.11 \%)$ \\
$81-90$ & 1 & $\mathbf{2 ( 2 2 . 2 2 \% )}$ & $\mathbf{2 ( 2 2 . 2 2 \% )}$ & $\mathbf{1 ( 1 1 . 1 1 \% )}$ & $\mathbf{9 ( 1 0 0 \% )}$
\end{tabular}

The present study is undertaken to study the diverse histopathological patterns of testicular lesions and thus offering a specific diagnosis which is of paramount clinical significance.

\section{MATERIALS AND METHODS}

After approval of the ethics committee and informed consent from the patients were obtained, a total number of 60 cases with testicular lesions were evaluated between November 2012 to October 2016.This was a cross-sectional observational study done in the department of Pathology of $\mathrm{B} \& \mathrm{~B}$ Hospital. The gross specimens received were fixed in $10 \%$ formalin. Gross examination of fixed specimen was done and the sections were taken from representative sites. The sections were stained with hematoxylin and eosin. Light microscopic study was done for diagnosis. Statistical analysis was done using EXCEL wherever necessary.

\section{RESULTS}

There were a total of 60 testicular biopsies reviewed during November 2012 to October 2016. Seventy percent (70\%) of these testicular biopsies were orchidectomy specimen and $30 \%$ were small biopsies. Thirty percent $(30 \%)$ of the total specimen comprised of undescended testis. Out of the total 60 cases, 15\% (9/60) were diagnosed as neoplastic lesions and $85 \%$ (51/60) were non-neoplastic lesions .Table 1 and table 2 shows age wise distribution and histological diagnosis of neoplastic and non-neoplastic lesions of testis respectively. As shown in table 1 testicular tumors were

Table 2 : Frequency of nonneoplastic testicular lesions at various age group

\begin{tabular}{llc}
\hline Age in years & Number of cases $(\mathbf{n}=\mathbf{5 1})$ & Percentage $(\%)$ \\
\hline $0-10$ & 2 & 3.92 \\
$11-20$ & 15 & 29.41 \\
$21-30$ & 9 & 17.64 \\
$31-40$ & 9 & 17.64 \\
$41-50$ & 6 & 11.76 \\
$51-60$ & 6 & 11.76 \\
\hline $61-70$ & 3 & 5.88 \\
$>71$ & 1 & 1.96 \\
\hline
\end{tabular}

more prevalent in the age group of 31-40 years. Only one case of Non-Hodgkin lymphoma was seen after 50 years of age. Out of the 9 malignant tumors in this study, $77.77 \%$ (7 cases) consisted of germ cell tumors.

Table 2 shows age wise distribution of non-neoplastic lesions of testis. Our youngest patient was at birth while the oldest patient was 71 year male. Maximum numbers of patients presented in second decade of life (29.41\%). Second highest age incidence was found in 3rd and 4th decade of the life, comprising 17.64\% each. Various lesions were observed in wide range of age. Torsion and infarction of testis was seen in 28 cases $(54.9 \%)$ followed by testicular abscess $(n=8 ; 15.6 \%)$. Since tuberculosis is more common in our context, tuberculosis of testis was found in 4 cases $(7.8 \%)$. (Table 3$)$

\section{DISCUSSION}

Though the incidence of testicular tumor is low, it is one of the most common malignancies occurring in young adults. In present study, most of the malignant cases were seen in $3 \mathrm{rd}$ and 4 th decade of life which was in accordance with reports from African and European series. ${ }^{6.7}$

According to the literature, the histologic pattern and behavior of the tumor differ with each age period. In young adults, seminoma, embryonal carcinoma, teratoma and teratocarcinoma are common but seminoma is more common in the fourth decade whereas spermatocytic seminoma and lymphoma occur in the elderly.

Table 3: Histopathological diagnosis of non-neoplastic lesions.

\begin{tabular}{lcc}
\hline HPE Diagnosis & $\begin{array}{c}\text { Number } \\
\text { of Cases } \\
(\mathbf{n}=\mathbf{5 1})\end{array}$ & Percentage(\%) \\
\hline Undescended testis & 4 & 7.84 \\
\hline T.B. Epididymo-orchitis & 5 & 9.80 \\
\hline Granulomatous Orchitis & 1 & 1.96 \\
\hline Testicular Abscess & 8 & 15.68 \\
\hline Non-specific Epididymo-orchitis & 5 & 9.80 \\
\hline Torsion and Infarction & 28 & 54.90 \\
\hline
\end{tabular}




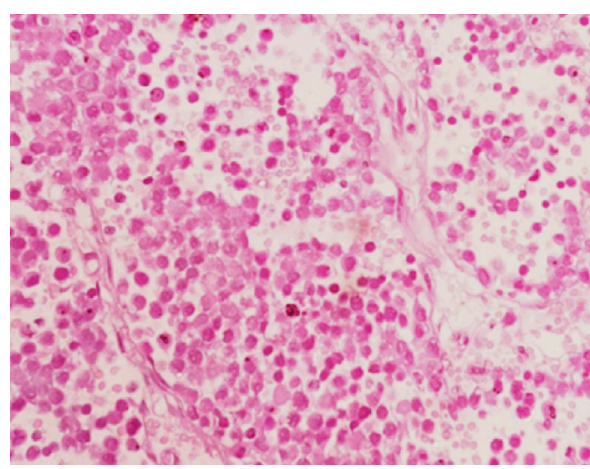

Figure 1: Seminoma: Nests of tumor cells separated by fibrous septae containing lymphocytes and plasma cells (HE stain $x 200)$.

Out of the 9 malignant tumors in this study, $77.77 \%$ (7 cases) consisted of germ cell tumors. According to Mostefi and Price, germ cell tumors constitute more than 94\% of testicular tumor. ${ }^{8}$ Among the 7 cases of germ cell tumors in this study $2(28.57 \%)$ were mixed germ cell tumors which is similar to that seen in other studies. In this study, a case of mixed germ cell tumor comprised of embryonal carcinoma and solid form yolk sac tumor, whereas other contained predominance of seminoma with choriocarcinoma.

Seminoma (fig.1) comprises $35-71 \%$ of testicular tumors. In this study, seminoma consisted of $44.44 \%$ ( 4 cases) of all testicular tumors.

Two cases (22.22\%) of Non-Hodgkin Lymphoma NHL (fig. 2 ) were encountered. One was seen in a 31 years old patient and the other one in a 65 years old patient. Both of them had diffuse large B-cell type Non-Hodgkin Lymphoma.

Fonseca et al reported median age of presentation of extranodal NHL to be 68 years. Primary testicular lymphoma accounts for approximately $1 \%$ of all lymphoma and is the most common malignancy in men more than 60 years of age. ${ }^{9}$

The reported incidence of leukemic infiltration of testis varies from $8 \%-25 \%$ in the literature, but in most studies this figure is less than 10 percent. ${ }^{10,11}$ Leukemic infiltration was not seen in this study.

Post pubertal (adult) testicular teratomas are malignant. Malignant testicular teratomas have a higher metastasis rate of $20 \%$ as opposed to their ovarian counterparts. ${ }^{12}$ Pure teratoma in the testis is rare accounting for $4 \%$ of GCT in this organ. Teratomatous features are more commonly found in mixed GCTs in the testis, rather than pure teratoma. In this study 1 case $(11.11 \%)$ was encountered with immature teratoma.

In the present study, for tuberculousepididymo-orchitis

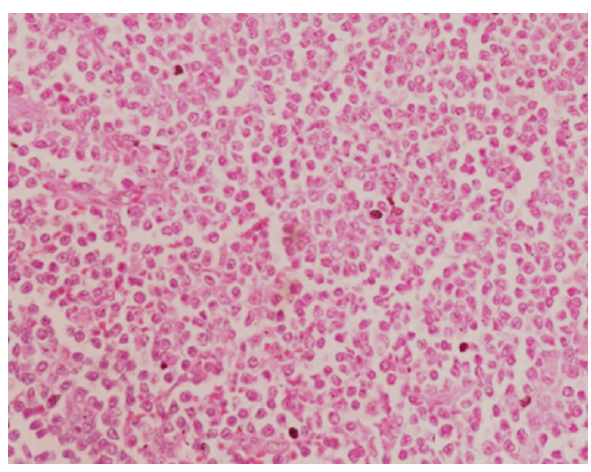

Figure 2: Non-Hodgkin lymphoma: proliferation of atypical neoplastic cells in diffuse sheets having indented nuclei and conspicuous nucleoli (HE stain x 200).

mean age was 49.6 years which is similar to Suankwan U et al. ${ }^{13}$ In the present study, a case of granulomatous orchitis whose age was 52 years which is similar to the study given by Grunberg $\mathrm{H}^{14}$ who found the prevalence to be the most common in $5^{\text {th }}$ to $6^{\text {th }}$ decade. There were 5 cases of nonspecific epidimymo-orchitis out of 51 cases $(9.80 \%)$. Age ranging from 21-60 years which is similar to the study given by Kaver et al. ${ }^{15}$

The most commonly found abnormality, torsion and infarction constituted $54.90 \%$ in the present study with the mean age 26.5 years which is similar tostudy given by Cuckow et al. ${ }^{16}$

\section{CONCLUSION}

The incidence of testicular neoplasm still remains low in our population which is reflected by the paucity of studies in published literature. Germ cell tumors accounted for highest percentage of subtype of seminoma followed by mixed germ cell tumor. Out of all non-neoplastic lesions, vascular lesions like torsion and infarction are the most common findings followed by tubercular abscess.

\section{REFERENCES}

1. Purdue MP, Devesa SS, Sigurdson AJ, McGlynn KA. International patterns and trends in testis cancer incidence. Int $\mathrm{J}$ Cancer. 2005; 15:822-27. Crossref

2. Power DA, Brown RS, Brock CS, et al. Trends in testicular carcinoma in England and wales, 1971-1999. BJU Int. 2001;87:361-65. Crossref

3. Muir CS, Nectoux J. Epidemiology of cancer of the testis and penis. National Cancer Institute Monographs. 1979;53:157-64.

4. Garner MJ, Turner MC, Ghadirian P, Krewski D. Epidemiology of testicular cancer: an overview. Int J cancer 2005;116:331-9. Crossref

5. Liu S, Wen SW, Mao Y, Mery L, Pouleau J. Birth cohort effects underlying the increasing testicular cancer incidence in Canada. Can J Public Health 1999;90:176-80. Crossref

6. Sagalowsky Al. Current consideration in the diagnosis and initial treatment of testicular cancer. ComprTher. 1994;20:688-90. Crossref

7. Richiardi L, Bellocco R, Adami HO, Torrang A, Barlow L, Hakulinen T. Testicular cancer incidence in eight northern European 
countries: secular recent trends. Cancer Epidemol Biomarkers Prev. 2004;13:2157-66. Crossref

8. Mostofi FK, Price EB, Jr. Tumors of the male genital system. Atlas of tumor pathology, fascicle 7, Series 2. Armed Forces Institute of Pathology; Washington D.C. 1973;pp1186-1200. Crossref

9. Vural F, Cagirgan S, Saydan G, Hekimgil M, Soyer NA, Tombuloglu M. Primary testicular lymphoma. J Natl Med Assoc 2007;99:127782. Crossref

10. Stoffel TJ, Nesbit ME, Livitt SH. Extramedullary involvement of the testis in childhood. Cancer 1975;35:1203-11. Crossref

11. Braren V, Lukens JN, Stroup SL, Bolin MG, Rhamy RK. Testicular infiltrate in childhood acute lymphoblastic leukemia. The need for biopsy in suspected relapse. Urology 1980;16:370-4. Crossref
12. Carver BS,All-Ahmadie H, Sheinfield J. Adult and Pediatric Testicular Teratoma. Urol.Clin.North AM 2007;34:245-251. Crossref

13. Suankwan U et al; Southest Asian J Trop Med Public Health; 2012;43: 951-8. Crossref

14. Grunberg H, Frankfurt Z. Three unusal cases of chronic orchitis clinically resembling tumors of testis. J.Pathol 1926;33:217-27.

15. Kaver I, Matzkin H, Braf ZF; Epididymoorchtis: a retrospective study of 121 patients; J Fam Pract;, 1990;30:548-52. Crossref

16. Cuckow P.M; Frank J.D.Torsion of testis. BJU Int. 2000;;86:349353. Crossref 